\title{
Research on the Construction of Business Management Specialty Group Based on Innovation and Entrepreneurship
}

\author{
Zhang Qin \\ Wuhan College
}

\begin{abstract}
Keywords: Business administration; Innovation and entrepreneurship; Ability development; Community building
\end{abstract}

\begin{abstract}
Mass innovation and entrepreneurship" is leading the development of the times. For this reason, many colleges and universities in China are integrating professional education with innovation and entrepreneurship education. The knowledge structure of the business administration profession has innate advantages in innovation and entrepreneurship. Business Administration is a basic course for Business Administration major. The characteristics of the discipline are characterized by strong practicality. The quality of management education directly affects the training of professionals in business administration. Therefore, starting from the teaching management design of the management community, this article continues to explore and deepen the teaching reform, and gradually forms a platform for characteristic teaching training, so as to effectively promote the training of business management talents. In addition, the implementation of the construction of the professional business administration group has also achieved great results. It is hoped that the colleges and universities will actively use the community management and promote the innovation and entrepreneurship of business management professionals.
\end{abstract}

\section{Introduction}

Management is a compulsory course for business administration majors and a basic subject for students to master basic management knowledge and theory. Management courses cover a wide range of applications. The demand for outstanding management talents from all walks of life is high. With the development of society and the intensification of competition among enterprises, employers have increased the recruitment standards for graduates of business administration, with particular emphasis on students' practical abilities and related social experiences. As the traditional teaching model only pays attention to the instillation of theoretical knowledge, the cultivation of students' practical ability is relatively lacking. Therefore, it is imperative to improve the training and innovation of managerial innovation talents and application capabilities. Course teaching is the basic approach to talent cultivation. Scientific, reasonable, high-quality and innovative teaching design is the basis for ensuring the effectiveness of the curriculum. With the progress of the times, the teaching design of management courses also needs to advance with the times. Therefore, increasing the professional group platform curriculum construction, broadening the teaching curriculum resources, and then cultivating the formation of high-quality, wide-caliber business administration talents are the current direction of the management design of the management courses.

\section{Conceptual Understanding of the Construction of the Professional Group of Business Administration}

The construction of the business administration professional group is based on the business management profession as a core specialty, and it is a process of collective development and construction of other related majors whose engineering objects are the same, technical fields are similar, or professional disciplines are similar. 


\section{Characteristics and Roles of Construction of Business Administration Specialty Group}

First of all, the construction of the industrial and commercial management professional group is an organization formed around the needs of the industrial and commercial management industry. There are similar service objects and similar management technologies within the professional group. Therefore, in the teaching, each major in the group can achieve the goal of sharing the resource system and jointly accomplish the teaching tasks. In the application and internship, it can also share the practice bases inside and outside the school. Secondly, the construction of the professional business administration group is the institution that the school has learned through long-term school experience, and through the degree of socio-economic development, the development and trend of the business management industry, combined with the school research philosophy. It can achieve reasonable integration, distribution and layout of teaching resources in schools. Since the majors in the professional group have the same subject basis and the professional theoretical foundation courses are connected with each other, it is bound to form a team of highly qualified and professional teachers to ensure the quality construction of professional business administration.

\section{The Necessity of Constructing Community Construction System}

\section{The Continuous Increase of Teaching Content}

With science and technology accelerating forward, human knowledge accumulates at an accelerating pace. The connotation of social work positions is also constantly changing, and a large amount of teaching content has flowed into the horizons of higher education courses, such as technology, environment, foreign language learning, foreign culture, business management, entrepreneurship education, innovation education, information education, leisure education and so on. These new additions will have a big impact on the existing curriculum. How can we add or delete educational content in a timely manner while ensuring the stability of the curriculum?

The introduction of community building has solved this problem. The curriculum structure of community building divides the educational content into several modules and meets different needs with different combinations of these modules. When new content is added, it merely expands the content of a course or adds new courses without having a significant impact on the overall curriculum. As a result, it is conducive to the stability of the curriculum. The professional curriculum module has a clear goal and short content, and it is also convenient for flexible combination to be arranged into courses that suit new needs. Small changes in the basic course touch block can also maintain the systematic nature, integrity and stability of its curriculum content.

\section{Personalized teaching}

The development of information technology allows people to choose a diversified lifestyle, including learning methods. Students' primary status in the process of receiving education is increasingly valued. It is an inevitable trend for curriculum development to focus on student-centered rather than teacher-centered curriculum. On the one hand, the community construction curriculum is flexible in structure and can adopt different learning methods. In terms of time, it can focus on learning as well as decentralized learning. Persons who have graduated from school and embarked on a job can also return to school at any time to choose what they need for their work. Course module for learning. On the other hand, as the use of information technology in teaching has brought revolutionary changes to traditional teaching, personalized teaching has become possible. According to their own level of knowledge and ability, hobbies, etc, students can self-decide to choose the way and means of education, and choose the learning progress. The same group of students can be in different learning community states or different stages of the same community.

\section{Change in Economic Growth Mode}

With the advent of knowledge economy, the status of large-scale industrial production in the social economy continues to decline, and people are moving from the era of atomic energy into the era of digitalization. Workers employed in large enterprises are declining, workers employed by small and medium-sized enterprises are increasing, and the development of small and medium-sized 
enterprises has become a new economic growth point. Based on the system of the construction of the business administration professional group, the talents needed for SMEs are also varied. Therefore, the concept of flexible manufacturing system should also be introduced in the training of talents. Talents of different types and specifications should be cultivated in small batches and in multiple specifications. Under a major, a number of different course modules should be set up for students to choose in order to meet the needs of society. .

\section{Diversity of School Subjects}

The establishment of a system of business administration courses can also be the creation of only a certain class of courses, and the main body of university education will be diversified. The community building structure of the course makes it possible for different subjects to communicate and connect. Each educational institution offers its own advantages courses. Students choose different courses in different educational institutions.

\section{The General Principles of Community Construction for Cultivating Innovative and Entrepreneurial Talents in Business Administration}

\section{Grasping the leading direction of cultivating innovation and entrepreneurship}

It is necessary to grasp the leading direction of construction of the business management professional community, reposition it, put the cultivation of innovation and entrepreneurship into an important position, and regard community building as an important extension and supplement of the traditional classroom.

The secondary colleges and universities shall incorporate the community building into the system of innovation and entrepreneurship education. The academic and youth league committees and the educational administration department shall form a leading group for community building, strengthen cooperation, and conduct in-depth research on the entrepreneurial market and the actual situation of the students. The construction will be in line with the market orientation. The community construction activities, such as specialized curriculum setting, practical training requirements, student-level discipline competitions, and Daiso projects, ensure that the practice of community building in colleges and universities meets the needs of fostering innovation and entrepreneurship. In the process of designing and organizing activities, the embedding of innovation and entrepreneurship elements and the coverage of students are taken into account. When the conditions for participation in the activities are appropriately relaxed, emphasis is placed on the expression of reward mechanisms so that more students can participate in the formation of the vast majority. Students have the opportunity to participate in the atmosphere of community building innovation and entrepreneurship activities, which is conducive to the overall improvement of students' innovation and entrepreneurship.

\section{Multi-agent cooperation of the guiding party}

The concept of a triple helix was first applied in the field of biology. Henry Eczewitz extended it and proposed the "three helix theory" of cooperation between government, industry, to describe the new interactive relationship between government, industry and universities in the era of knowledge economy. At present, government departments, industry enterprises, and universities and colleges are the three major elements of the innovation and entrepreneurship system. When the three forces interact, they can form an incalculable synergy based on specific needs. The project of innovation and entrepreneurship in the construction of college business management communities should be close to reality, and cooperation with industry enterprises is relatively straightforward and effective. If you want to obtain policy and financial support, you will need support from the relevant government departments. When the secondary schools and faculties design business management community construction activities, they must prioritize the integration of the three parties' resources to find a point of convergence that will facilitate the sustainability and vitality of the activities.

\section{Integration with professional courses}

The activities of the professional community for business administration and management must be integrated with the teaching content of professional courses, and professional education cannot be ignored. Students will feel that they are useless and have a prejudice against the profession. 
Traditional classroom teaching and community building activities should be mutual promotion and sharing of teaching resources. Classroom teaching is a place for students to acquire professional theories of business management. While the community building is a stage where students consolidate what they learn in the first class, apply theory to practice, develop innovative thinking, and improve their ability to find problems, analyze problems, and solve problems.

On the one hand, in the revision of the talent training program, the secondary colleges and universities should create innovative entrepreneurship curriculum modules according to specific conditions. The design of the practical teaching link should be effectively linked with the activities of the community building, and the community building should be truly integrated with the professional curriculum teaching. On the other hand, secondary schools should match the content of professional teaching as much as possible when designing community building activities. This requires the Communist Youth League and full-time teachers to strengthen communication and optimize design..

\section{In-depth participation of full-time teachers}

Colleges and universities should guide and encourage full-time teachers to participate in the activities of the business management community building activities. The second-tier colleges and universities can explore the "project mentoring system" for community building innovation and entrepreneurial activities, integrate the teachers of the university and cooperative enterprises, and provide professional mentors for each entrepreneurial team, and participate in the whole process of guidance and joint practice. When the teaching department calculates the amount of teaching tasks for full-time teachers, it will calculate the amount of class time according to the type of projects that participate in community building. The standard of translation should be increased as much as possible, and the enthusiasm of full-time teachers to participate in community building should be mobilized. On the other hand, colleges and universities should consider the top-level design, list the topics of innovation and entrepreneurship in school-level topics, and promote full-time teachers to make their own professional community-building activities their own research goals and directions, and devote themselves to the guidance and cooperation of students. While completing the research of the project, it also leads students to complete a complete entrepreneurial practice.

\section{Test of return to social practice}

Colleges and universities should actively create the atmosphere for college students to participate in various kinds of skill contests and entrepreneurial activities. After all, the entrepreneurial and practical skills that students learn in community building school activities must return to the real environment to test and further improve. Colleges and universities should provide more opportunities for college students to participate in innovation and entrepreneurship training projects, enterprise ERP sand table simulation business competitions and other innovative and entrepreneurial activities, so that students can apply the theoretical knowledge learned in the classroom to the actual combat, and creatively play and accumulate in practice. experience. Colleges and universities should also establish support mechanisms for college students' innovation and entrepreneurship projects, and provide support in policy advocacy, tutor guidance, venue provision, and financial support. It's beneficial for entrepreneurial teams who are interested in starting their own business and achieving certain achievements in community building activities to enter the "start-up business incubator park for university students", to help them further their entrepreneurship and drive more employment opportunities for business management majors to achieve a virtuous circle.

\section{Summary}

The reform of the teaching design of the professional management course for business administration is long way to go. The construction of professional groups is an important breakthrough and resource for teaching reform. In the implementation of specific instructional design, teachers and students must constantly update their curriculum concepts to meet the changing needs of society and enterprises. Intensify the control of curriculum design on practical ability, and gradually improve the assessment methods, and finally achieve the goal of cultivating outstanding 
application-oriented business management talents for the country and society.

\section{References}

[1] Fafaliou I, Melanitis N E, Tsakalos V. Commercialising research results in immature technology transfer markets: cases from the Greek experience[J]. International Journal of Entrepreneurship \& Innovation Management, 2010, 11(2):213-227.

[2] Devece C A, Palacios-Marques D, Fernandez R. Entrepreneurship research in service industries: a literature classification and trend analysis[J]. International Entrepreneurship \& Management Journal, 2011, 7(4):479-493.

[3] Deng Y, Chen S, Wu L, et al. Research of Cultivating University Students, Innovation Ability based on Technological Competition[C]// 2nd International Conference on Management Science and Industrial Engineering (MSIE 2013). Atlantis Press, 2013.

[4] Brandão Fischer B, Molero J. Journal of Technology Management \& Innovation[J]. Journal of Technology Management \& Innovation, 2014.

[5] Etzkowitz H. Making a humanities town: knowledge-infused clusters, civic entrepreneurship and civil society in local innovation systems[J]. Triple Helix, 2015, 2(1):1.

[6] Teece D J, Al-Aali A Y. Knowledge, Entrepreneurship, and Capabilities: Revisingthe Theory of the MNE[J]. Universia Business Review, 2013, 40(40):págs. 18-33.

[7] Hülsbeck M. Entrepreneurship Policy in Bavaria: Between Laptop and Lederhosen[J]. Handbook of Research on Entrepreneurship Policy, 2015.

[8] Chawla M. Study on Cluster Entrepreneurship of Haryana[J]. International Journal of Commerce \& Business Management, 2013.

[9] Carayannis E G, Sindakis S, Walter C. Business Model Innovation as Lever of Organizational Sustainability[J]. Journal of Technology Transfer, 2015, 40(1):85-104.

[10] Nielsen K. Human capital and new venture performance: the industry choice and performance of academic entrepreneurs[J]. Journal of Technology Transfer, 2015, 40(3):453-474.

[11] Nithyananda K V. Teaching the Elective, "Legal Aspects of Innovation and Entrepreneurship" to Management Students[J]. 2017.

[12] Tan J Y, Division A A, University T N. Practice and exploration of the funds management in the undergraduate innovation and entrepreneurship training program $[\mathrm{J}]$. Laboratory Science, 2017.

[13] Amoroso S. Multilevel heterogeneity of R\&D cooperation and innovation determinants[J]. Eurasian Business Review, 2017, 7(1):1-28.

[14] Leal-Millan A, Peris-Ortiz M, Leal-Rodríguez A L. Sustainability in Innovation and Entrepreneurship: Policies and Practices for a World with Finite Resources[J]. 2018. 